\title{
REVIEWING LEXICOLOGY OF THE NUSANTARA LANGUAGE
}

\author{
Mohd Yusop Sharifudin \\ Universiti Putra Malaysia \\ Email:mosy@upm.edu.my
}

\begin{abstract}
The strength of a language is its ability to reveal all human behaviour and progress of civilization. Language should be ready for use at all times and in any human activity and must be able to grow together with all forms of discipline and knowledge. Languages that are not dynamic over time will become obsolete, archaic and finally extinct. Accordingly, the effort to develop and create a civilisation needs to take into account also the effort to expand its language as the medium of instruction. The most basic language development in this regard was to look for vocabulary that could potentially be taken to develope a dynamic language. This paper shows the potential and the wealth of lexical resources in building the Nusantara language to become a world language.
\end{abstract}

Keywords: Lexicology, Nusantara Language

\section{Introduction}

Language is an important means for humans to communicate and build interaction. Language is basically a means of communication within community members. Communication takes place not only verbally, but also in writing (Sirbu 2015, 405). language is also a tool that shows the level of civilization in humans (Holtgraves et al. 2014, 230).

In order to play an important role as a means of developing civilization, language must continue to develop dynamically over time and enriched according to the needs and development of civilization. Likewise the case with Nusantara Malay language. This paper aims to describe how to develop Nusantara Malay language through the development of various Malay vocabularies. Does Nusantara Malay have rich lexical sources that can be developed as a medium of instruction in the dynamics of modern society today? Can the development of shared vocabulary of Malay language make Malay language the world language?

So far, research on the development of Malay lexical sources has been carried out by several experts. Among the research conducted by Tan which concluded that the systematic underlying process involved is reflected in linguistic results, and that there is much potential for corpus-based lexicography where I have an interest. To highlight the danger of borrowing phenomena, social and language factors that motivated ME users to include Malay lexical features in various English they were examined (Tan 2009, 11).

Furthermore, research conducted by Liow, Jalil and Faizal stated that separate hierarchical regression analysis for Malay and English revealed how the consistency of phonological orthographic mapping modulates the effects of different lexical variables on lexical decisions and the speed of pronunciation performance (Yap et al. 2010, 992). The research carried out by Don was the first attempt to produce a work system for the automatic processing of 'Malay' texts. At the heart of the system is an integrated relational lexical database called MALEX, which utilizes working experience in English and other languages, but which is specifically adapted to Malay conditions (Mohd Don 2010, 90). Based on several 
previous studies, researchers were interested in conducting a review of previous studies on lexical languages in the archipelago.

\section{The Dynamism of Nusantara Language}

Generally the term 'Nusantara' refers to the region comprising sea of thousands of islands that are separated by a narrow straits and in Southeast Asia. This term is made up of a combination of two words from ancient Javanese language; 'nusa' which means island and 'antara'which means separated apart. The island stretching from Taiwan in the northand to Cocos island in the South, and from Timor Leste in the east to Madagascar in the west. Scholars and Western traveler named the Islands as The Malay Archipelago, term created by Alfred Russel Wallace, 1869 which means Islands that are dominated by the Malay race (Smith 2010, 391).

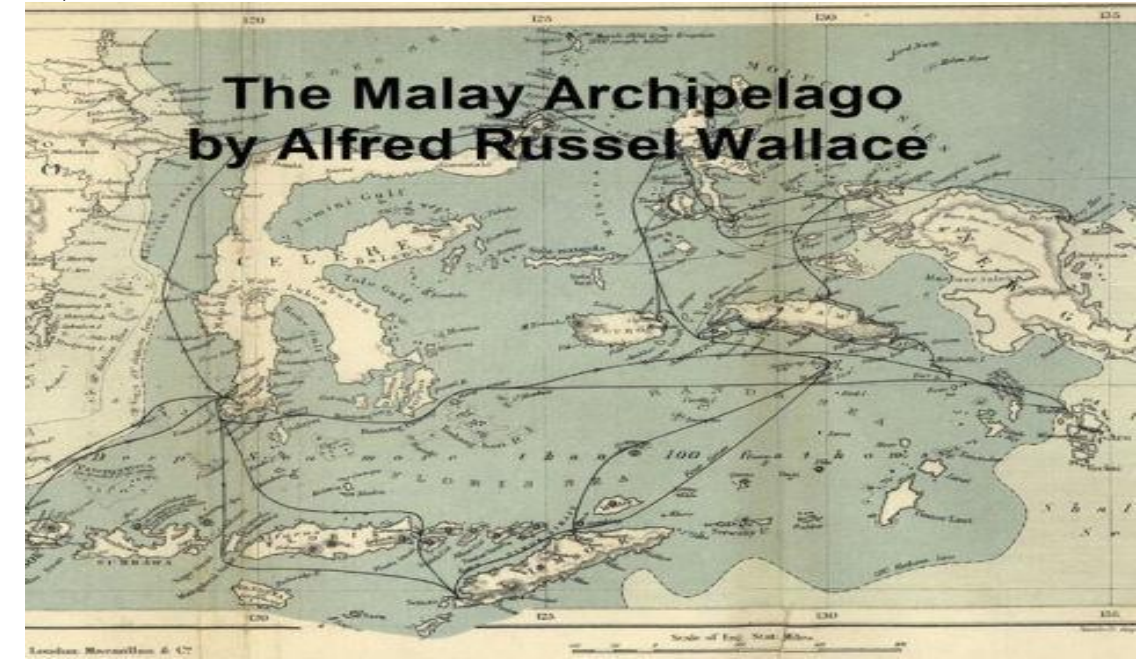

In modern terminology, Nusantara refers to the range of cultural and linguistic influence of the Malays which includes the islands of Indonesia, Malaysia, Singapore, parts of southern Thailand, southern Philippines, Brunei, East Timor and may also be Taiwan, but it does not involve the district of Papua New Guinea. The term matches for Nusantara in bahasa Malaysia is Malay and bahasa Indonesia is Nusantara, although this term is now widely used in Malaysia (Barnes \& Noble n.d.).

\section{Malay Archipelago}

With an estimated number of more than 350 million residents, most of the languages spoken in the province of the region is part of the Malayo-Polynesian family, including Tagalog language widely spoken in the Philippines, the Javanese language spoken on the island of Java and the Malay language spoken in Malaysia (also known as bahasa Malaysia), Singapore and Brunei (which remained known as Malay) (Gutman and Avanzati 2013). Bahasa Indonesia is also derived from the Malay and officialy known as Indonesian language in accordance with the "Sumpah Pemuda 1928" (Setyabudi 2017, 157).

Varieties of quarter and race create modes and dialects makes the language very rich and dynamic to grow in line with the movement of the time. According to the Ethnologue, there are 136 dialects in Malaysia, and 719 regional languages in Indonesia. This small languages skilled wealth appropriate lexical corpus specifically introduced as term to reveal the progress of human civilization. Mobilisation of theses resources can improve language ability and dignity thus proving the relevance of Nusantara and it significant as the language of the world (Ethnologue n.d., n.d.). 
History has also proved the Malay language used to beknown as lingua franca in the 14 th century to the 20th. It is not only spoken by people in this region but also become the language of choice in communications; among people of Southeast Asian also between missionaries, merchants and explorers from the East and West (Kirkpatrick 2011, 2). Even the Italian (which their existence as conquerors in Southeast Asia is not known like the English, Dutch, Portuguese and French), has documented lexical of the Nusantara with the creation of Italian-Malay word lists by Antonio Pigafetta in 1522. The word lists also previously been published in the form of Latin-Malay and French-Malay. Produces at the time when he was in Brunei and Tidore which is about $2000 \mathrm{~km}$ from the Straits of Malacca, Pigafetta has gathered Malay lexicals confirming its status as the main language in this region (Ferdinand Magellan's 1525).

A year earlier; in 1521, there is also documented evidence in the Malay language used in diplomatic relations between the Malay sultan; Sultan Abu Hayat of Ternateto the King of Portugal, King John III. Documents written in the Jawi report on Sultan Abu Hayat related unrest happened in Maluku islands show that Malay already recognised as an international language at the highest level which achieves the status of diplomatic languages between the two (Sharifudin 2017, 4).

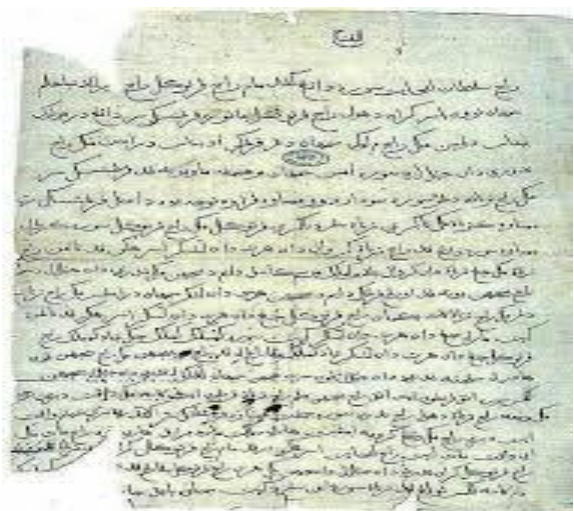

About 250 years later, on the other hand there was such a letter written by European leader to a Malay sultan; that is to say the letter written by General Reynier De Klerk, a Governor of Dutch-Indies to King of Palembang, Paduka Seri Sultan Ratu Muhammad Baha'uddeen. This diplomatic letter revolve around bilateral relations both the Government and the country, thus showing proof that the European nation also already fluent in Malay and was able to write such a letter and written using the Jawi letters (Teh Gallop n.d.).

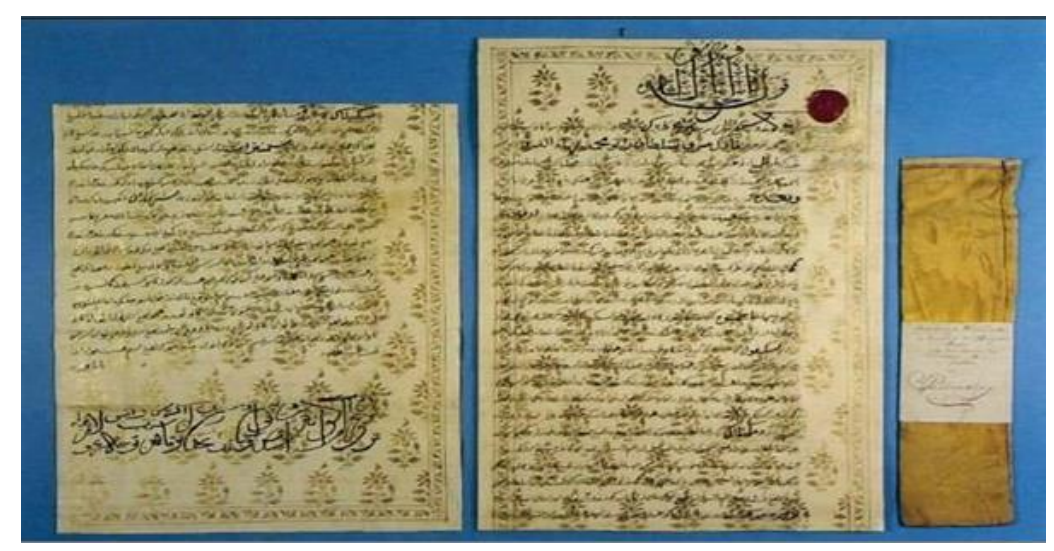

"Bahawa Gurnadur Jenderal Reynier de Klerk dan sekalian Raden van India berkirim ini surat ikhlas sahabat-bersahabat dan berkasih2an kepada sahabat handai taulannya Paduka Seri 
Sultan Ratu Muhammad Bahauddin, raja atas tahta kerajaan Palembang, dipohonkan atasnya sihat dan afiat serta daulat dan segala berkat yang boleh membahagiakan pada sendirinya beserta rakyat2nya istimewa pula sahabat-bersahabat pada antara Tuan Sultan dengan kompeni Wolandawi, boleh tinggal tetap dan tegoh hingga zaman yang mutakhirin adanya."(Sharifudin 2017, 4)

Such achievement is enough to prove that Malay should not be debased, but duly appointed as one of the languages of the world. However since leaving its lingua franca status due to socio- cultural and political colonization of the West by the 19th century, the Malay language had to deal with the tide of modernization brought by the so call orientalist and rises to a crisis of self- confidence among native speakers to rise again. Malay became separated, by the divide and rule policy transforming its label making it bahasa Malaysia in Malaysia (although still registered as Malay language in the Constitution of Malaysia), bahasa Indonesia and bahasa Melayu in Indonesia in Brunei, Singapore, southern Thailand and southern Phillipine.

The speakers which is now seen to have an identity of language according to their respective nation and increasingly fail to communicate without creating conflict although often claimed to be brothers. Various stigma created; it's an old language, not economical, difficult to faced modernisation, unfriendly to science and technology, not interpretibility, etc. A number of speakers to still want to be English or Dutch, although it appears to be that the tribal language lexical corpus and dialects still very rich to serve the rise of a new civilization.

\section{The Challenge Now}

Indeed there is no denying that the modern world is now very dependent on science and technology. From West to East and from North to South, people are faced with the challenge of developing our very own dynamicsmaterial. Creation and dissemination of information requires powerful language as its medium. During the era of feudalisme, the slogan worn is "the strongest will ruled", but now that it's been turned into a slogan "the informed will rule".

Nusantara language should face this challenge and need to be dynamic so as to remain relevant and able to translate the world civilisation which transformed rapidly. The main strength that needs to be built was in terms of vocabulary and terminology to be used for translating and reveal the new sciences that is created and dispersed every seconds. Recently, various parties in Malaysia including the Dewan Bahasa dan Pustaka has published over 300 dictionary and glossary covering various fields including science and technology.

A total of more than 880000 terms has been created to be used in various fields. Undoubtedly a large part of the vocabulary are based on foreign vocabulary which has been through the process of loan-translate. But keep in mind, as a comparison, there aren't a singgle language who is able to rely on its own resources, considering the whole world now has gone borderless. In fact, the so-called English already regarded as lingua franca of the world also actually borrowed almost $70 \%$ lexical from 350 other languages, especially Latin (Dictionary n.d.).

With the assumption that the crisis of confidence in the Nusantara languages stems from the lack of resources causing vocabulary to become clise, this paper suggests the entire language lovers make the Archipelago language and dialect as the most desirable option. Collins (1986) once stated that; 
"... each Malay dialect is part of the Malay cultural assets that must be guarded, learned and preserved desperately. Loss of a Malay dialect should be deemed to be the same great calamity with the sinking ship Raffles means transporting copies of Malay manuscripts to Europe. Don't get wealth modes Melayu language whatsoever in the current sinking urbanisation and modernisation now wind storm hit Malaysia."

\section{Further Steps}

For the first time in the Asia-Pacific Parliamentary Forum (Asia Pacific Parlimentary Forum) held in Ulaanbaatar, Mongolia in January 2011, the language of the region is used as one of the medium of communication. Indonesia, Brunei, and Malaysia has consensusly used it together with the six other languages namely Mongolia, Chinese, Japanese, Korean, Russian, and English. Although its use is not completely usedbut as language of the region, especially ASEAN and world, this languages generally began to be noted by the 27 participant countries (Anudari n.d.).

Realising the potential, this article further suggested;

\section{Exploration}

With so many sources of lexical dialect and language areas are still hidden in the store of their native speakers respectively, as well as the wealth of a term that has been produced, quite unfortunate if all of it or part thereof is not utilized. In the languages of the situation being faced with the threat of obsolescence and extinction, research efforts, documention and maintenance must be executed as soon as possible. For example, the following resources can be utilized.

\section{Sarawak Native Languages}

-/ampus/(Sarawak Malay) = asthma >asma

-/awah/(Kayan, Kenyah, Bidayuh, Kelabit, Lun Bawang) = corridor $>$ koridor

- $/$ rue ay/(Iban, Bidayuh) = lobby>lobi

- $/$ gadar $/($ Melanau $)=$ transparent $>$ lutsinar

- /mararaw/(Iban) = lunch $>$ makan tengah hari

-/randaw/(Iban) $=$ dialogue $>$ dialog

-/sa®kalan/(Sarawak Malay) = chopping board>landas cincang

-/dugal/(Bajau, Sarawak Malay) = gastric $>$ gastrik

\section{Kayan Language}

-/tibah/= honourorium $>$ honorarium

-/mutaw/= engine $>$ enjin

- /huwin $/=$ access $>$ akses

-/lu®/=anthology> antologi

-/buhup/= album> album

- /ayan/= size $>$ saiz

-/tulan/= section $>$ seksyen

$\bullet /$ na®an/= category $>$ kategori

-/bae at/= elastic $>$ elastik

-/bire®/> blind > buta sebelah mata 


\section{Sabah Native language}

- $/$ tuhunan $/($ Pink $)=$ cussion $>$ kusyen

-/kisus/(Kadazan-Dusun) = screw drive $>$ pemutar skru

- $/$ pantan/(Kadazan, Bajau) = stop bleeding $>$ menahan darah keluar

- $/$ maridap $/($ Bajau $)=$ nap $>$ tidur sebentar

\section{Perlis Dialect Resources}

-/anu» a® /- wheelbarrow = kereta sorong

-/banti®a®/- signboard = papan tanda

- $/$ pupoh/-signage prohibition = papan tanda larangan

-/anaw/- sex maniac = kemaruk seks

-/gaye®/= shoddy, used = barangann terpakai

-/gusti/- installment = bayaran secara ansuran

-/kalampu®/- balloon = belon

-/lam/= interpreters/translators = juru bahasa/penterjemah

-/calu@/= walker = alat bantuan berjalan bayi

\section{Sumber Bahasa Orang Asli}

-/yoka®/= > biscuit = biskut

$\bullet /$ keben $/=$ creamy = biskut berkrim

$\bullet /$ gasa®/= radio = radio

- $/$ pantiu® $/=$ radio = radio

Various forms of recognition and appropriate incentives should be consider to promote comprehensive research activities deemed the corpus. This is because too little funding in researching languages and dialects Nusantara. Research grant fair populated and institutions of higher learning should be given space to do more exploration and researche to unveil the resources.

\section{Legal and Socialization}

All parties including language bodies, scholars and consumers must work together to customize and popularise the lexical resources. In this case, of course, an element of political power could help, especially in terms of enforcement, providing recognition and incentives, or through teaching methods and formal learning methodes and technic. Branding the Nusantara languages according to the concept of nation State cause bahasa Malaysia and bahasa Indonesia for example increasingly misunderstanding mutually. Many situations including in such a forum involving participants both countries had to use a third language, especially English, simply because when using the language of the region, the longer the session will trigger loss of words. Many incidents of friction between the brothers who spokes the same language happens just because misunderstanding meanings of words like; 'gampang', 'butuh', 'percuma', 'kabur', 'korban', 'tewas', 'pejabat', 'rapat', 'repot', and a list of words that are getting longer. 
Another syndrome that should be avoided are 'hidding' of research finding that become part of the corpus of language Nusantara researchers. Results and review data stored in documents only as academic paper, journals and books which are hidden in the library. Although there are presented at seminars and conferences like this, the participants present is specific and often from amongst academicians only. It is rare public users interested to participate in such sessions because of the difficulty to digest the input delivered. This difficulty is also a result of

'abstract' presentation made by presenters such as like to maintain the status quo of academia without willing to educate the community and make use of their research results to be customized by the community.

\section{Role of Institutions of Higher Learning}

If the phenomenon of hidding data the language unable to be under control, then the final step and most important on everything is education initiatives and the necessary language sharing undertaken by institutions of higher learning. Corpus of local languages and dialects should be benefited formally in the classroom and in the lecture halls. These efforts can be implemented either by adding elements of that language in the existing curriculum or creating new courses and subjects. While there are still the native speakers can be a source of reference, appropriate parties concerned take opportunities to figure out and start it.

\section{Discussion}

The Power of Nusantara Language

Based on the findings and analysis of the researcher, one of the things that needs to be discussed is the strength of the language of the archipelago. How does the language of the archipelago affect human life. The power of language is its ability to express all human behavior and the progress of civilization. Language must be ready to be used at any time and in every human activity and must be able to grow together with all forms of discipline and knowledge.

Language can unite a nation that has a pluralistic society. Language makes all different people the same. Having similarities in a language makes them united. Feel that it is an inseparable whole. That is one of the strengths of the language of the archipelago. As a unifying language of the nation.

\section{Nusantara Language and Civilization}

Languages that are not dynamic from time to time will become obsolete, ancient and eventually extinct. Thus, efforts to develop and create civilization need to take into account efforts to expand the language as a medium of instruction. The most fundamental language development in this case is to find a potentially taken vocabulary to develop a dynamic language.

\section{The Language of The Archipelago as A World Language}

Based on the discussion above, that the language of the archipelago can be the language of this world if the strength of language in the form of human civilization has been strengthened. The way to enrich it is by developing and creating new vocabulary that can be accepted by everyone. 


\section{Conclusion}

This research study concluded that potential of Nusantara language to be promoted as one of the world languages is something that is not impossible. By the number of speakers within the tenth largest, user of Nusantara language is already available. Itonly has to deal with the crisis of confidence on deck of the limitations of vocabulary to reveal the progress of world civilization based on science and technology. After all, Quran and Sunnah also conclude the:

"Speaks to humans in accordance with the rate of their intellect" (H.R. Muslim).

"God will not send a Messenger except he should clarify in his language" (Ibrahim: 4) "And between the evidence of His (greatness) is the creation of the heavens and the earth difference languages and colors (skin) in it there is evidence (the greatness of God) for those who are knowledgefull."

(Ar-Rum: 22)

Hence bahasa menunjukkan bangsa, future of the Nusantara people depends on the dynamic of Nusantara language. The potential to be one of the world language is something that is not impossible. 


\section{Bibliography}

Anudari, M. "MPs Attending Meeting of the Asia-Pacific Parliamentarian Forum on Global Health." http://montsame.mn/en/read/16475 (November 4, 2018).

Barnes \& Noble. "The Malay Archipelago by Alfred Russel Wallace I NOOK Book (eBook) |

Barnes \&amp; Noble®." https://www.barnesandnoble.com/w/malay-archipelagoalfred-r-wallace/1100544166?type=eBook (November 3, 2018).

Collins, J.T. 1986. Antologi Kajian Dialek Melayu. Kuala Lumpur: Dewan Bahasa dan Pustaka.

Dictionary. "Which Words Did English Take From Other Languages? - Everything After Z by

Dictionary.com." dictionary.com. https://www.dictionary.com/e/borrowed-words/ (November 4, 2018).

Ethnologue. "Indonesia I Ethnologue." https://www.ethnologue.com/country/ID (November 3, 2018a).

- - -. “Malaysia I Ethnologue." https://www.ethnologue.com/country/MY (November 3, 2018b).

Ferdinand Magellan's. 1525. Jurnal Magellan's Voyage. Universitas Yale.

Gutman, Alejandro, and Beatriz Avanzati. 2013. http://www.languagesgulper.com/eng/Austronesian.html (November 3, 2018).

Holtgraves, Thomas M., Yoshihisa Kashima, Emiko Kashima, and Evan Kidd. 2014. "Language and Culture." In The Oxford Handbook of Language and Social Psychology,.

Kirkpatrick, Andy. 2011. "English as an Asian Lingua Franca and the Multilingual Model of ELT." Language Teaching.

Mohd Don, Zuraidah. 2010. “Processing Natural Malay Texts: A Data-Driven Approach." Trames.

Setyabudi, Titis. 2017. "Language Policy in Indonesia."

Sirbu, Anca. 2015. Equot;Mircea Cel Batran\&quot; Naval Academy Scientific Bulletin, Volume XVIII-2015-Issue 2 The Significance of Language as a Tool of Communication. http://www.thefreedictionary.com/dialect.

Smith, Charles H. 2010. "Alfred Russel Wallace, Geographer." Geography Compass.

Tan, Siew Imm. 2009. “Lexical Borrowing in Malaysian English: Influences of Malay.” Lexis.

Teh Gallop, Annabel. Malay manuscript art: the british library collection.

Yap, Melvin J., Susan J. Rickard Liow, Sajlia Binte Jalil, and Siti Syuhada Binte Faizal. 2010. “The Malay Lexicon Project: A Database of Lexical Statistics for 9,592 Words." Behavior Research Methods. 
REVIEWINGLEXICOLOGY OFTHE NUSANTARA LANGUAGE

Mohd Yusop Sharifudin 